\title{
International Medical Society of Paraplegia - 11 years on
}

\author{
H L Frankel MB FRCP
}

Consultant in Spinal Injuries, Stoke Mandeville Hospital, Aylesbury, HP2 18AL, England.

It is now more than 11 years since the death of Sir Ludwig Guttmann, founder president of the Society. Since that time, the Society has expanded under the determined and dynamic presidencies of the late Sir George Bedbrook, Dr Alain Rossier and Dr Ed Carter. The success of the Society's journal Paraplegia under the editorship of Phillip Harris is described elsewhere in this thirtieth anniversary issue. Apart from its journal, the main activities of the Society are its annual meetings, its regional meetings and its educational and scientific activities throughout the world.

In earlier years, annual scientific meetings were held at Stoke Mandeville, except in Olympic year. Now the meetings are at Stoke Mandeville every fourth year and most members feel that this is about right meetings at Stoke Mandeville always make a good profit! Stoke Mandeville remains the 'business headquarters' of the Society and this aspect of the Society has been consolidated by a financial adviser, Bernard Anson, and by our business manager, David Clay. Isaac Nuseibeh took over as honorary secretary and Brian Gardner as honorary treasurer. Paul Dollfus as chairman of the scientific committee has made considerable progress in coordinating scientific matters, but it is difficult to get international agreement on many subjects. English remains the official language for the Society though there are some requests for simultaneous translation into and out of various languages.

Due to the generosity of the Fondation Suisse de Paraplegiques, under the leadership of Guido Zach, the 'Swiss Fund' was set up. This has allowed the Society to recruit members at reduced subscription rates in many developing countries and to distribute Paraplegia worldwide.

With the development of strong, national and regional societies of Paraplegia, the position of IMSOP is gradually changing. It remains the central coordinating body for these societies and has full responsibility for all those countries who have no national organisations. IMSOP is still a society of individual members. This may change, but it will always have a central role in ensuring that spinal cord injured patients receive the best possible treatment in well integrated centres. 